\title{
高齢者の運動動機と身体活動性 および基礎体力の関係
}

\section{大友昭彦*1 渡辺京子*2 土屋滋*3 田中正敏*1}

Key words : 運動動機 (exercise motive), 身体活動性 (physical activity), 基礎体 力 (basic physical fitness), 高齢者 (elderly people)

目旨

高齢者の運動動機と身体活動性および基礎体力の関係
大友昭彦
渡辺京子
土屋 嵫
田中正敏

高齢者の健康づくりを目的とした運動指導の意義は大きい.この場合，運動に対 する動機や意欲といった心理的側面の作用も見逃せない。そこで高齢者の運動動機 と身体活動性，基礎体力の関係を明らかにする目的で調査を行った．養護老人ホー ムおよび軽費老人ホーム入居の 110 名の男女を対象とし，独自に開発した高齢者用 運動動機尺度および歩数，握力，脚力，肺活量を調査した，重回帰分析の結果，高 齢者用運動動機尺度得点は性，年齢，身長，体重の要因を除外しても，歩数，握力， 脚力，肺活量に有意な関連性を示した。これにより，運動動機が高齢者の身体運動 に寄与することが客観的に示され，運動指導面で運動動機を考慮することの重要性 が示唆された。

\section{リハ医学 $33: 400-406,1996$}

\section{はじめに}

高齢者の健康づくりにおいて適度な運動は欠くべか らざる要素であるが，その実行には，運動を行う動機 や意欲というた心理的側面の作用も見逃せない. 言い 換えれば的確な動機づけを行うことで，高齢者の運動 習慣が促進されることが期待できる。 また，地域機能 訓練事業をはじめとする地域リハビリテーションでは 対象の障害はすでに慢性化していることが多く，運動 指導の目的は機能回復という意味合いから体力維持や 健康管理，ひいてはグループワークを通した仲間づく りといったものとなっている。この場合重要なのは運 動プログラムを与えることではなく，そういった目的
の媒介となる運動を行ってもらうためにはどういう配 慮をなすべきかということである。これには高齢者の 運動に対する動機や意欲を客観的に考察しておかなけ ればならない.

動機と運動能力の関係についての研究は，体育教育 学やスポーツ科学の分野で, 学童や競技者を対象とし て行われているが1 6), 高齢者を対象とした研究は少な い. 運動動機测定尺度も, 従来の学童や競技者のもの は，質問項目の内容が高齢者に適しておらず，そのま ま適用できないものと思われる.われわれはこれまで, 高齢者に適した運動動機の測定尺度「高齢者用運動動 機尺度（表 1 )」の開発を試み，その妥当性と信頼性の 検討を行ってきた ${ }^{7,8)}$. 本研究では上記尺度を用いて， 高齢者が運動を行う動機の強さと身体活動性および基

1995 年 8 月 9 日受付, 1996 年 4 月 1 日受理

*1福島県立医科大学衛生学教室/ $9986-12$ 福島市光が丘 1

*2龟田総合病院リハビリテーションセンター/テ 296 鴨川市東町 929

*3筑波大学社会医学系/ 305 つくば市天王台 1-1-1 
あなたがなさっている日々の運動について，あなたのお気持ちをお聞かせ下さい，弚う思う時は 「乥う思う」，兰う思わない時は「关う思わない」，どちらとも判断がつきかねる場合や，自分にはあ てはまらない事柄であるという場合は「どちらでもない」を選んで○で囲んで下さい

I．身体を動かすことは楽しい。

2. 運動なんておっくうだと思うことがある.

弚う思う・弚う思わない・どちらでもない

3. 運動は心臟や関節の負担になる。

ある・ない・どちらでもない

4. 社会の一員として活動していきたいから運動をしなければいけない.

弚う思う・兰う思わない・どちらでもない

5．手足の動きが悪いので運動はつまらないと思うことがある.
6. 汗を流すほど運動がしたい．
ある・ない・どちらでもない

7.もっと歳をとっても，今の運動を続けていくだろう.

8. 運動をすると老化現象を防止できる.

弚う思う・关う思わない・どちらでもない

9. 毎日の運動は欠かすことができない

10. 運動をしていると，世の中のわずらわしさを忘れられる。

乥う思う・乥う思わない・どちらでもない

弚う思う・乥う思わない・どちらでもない

II. 運動が終わると，さっぱりした気分になる。

乥う思う・乥う思わない・どちらでもない

なる・ならない・どちらでもない

12. 運動はボケ防止につながる.

弚う思う・关う思わない・どちらでもない

13. いつまでも仕事をしたり旅行をしたりしたいから，運動することは大切だ.

弚う思う・乥う思わない・どちらでもない

14. 病気や障害を克服するために運動は良い方法だ.

弚う思う・关う思わない・どちらでもない

15. 毎日運動していると必ず身体が元気になる。

16. 運動を始める前にわくわくする。

弚う思う・关う思わない・どちらでもない

17. 運動なんかして転びでもしたら困る.

する・しない・どちらでもない

18. 運動すると友達とわいわいできて楽しい.

弚う思う・关う思わない・どちらでもない

弚う思う・乥う思わない・どちらでもない

19. 運動すると気分が明るくなる。

20. 身体が衰えたので運動はいやだなと思うことがある.

关う思う・乥う思わない・どちらでもない

ある・ない・どちらでもない

(採点 項目 1，4，6，7，8，9，10，11，12，13，14，15，16，18，19は，「弚う思う」もしく は「なる」, 項目 2，3，5，17，20 は「关う思わない」もしくは「ない」を選択した場合,

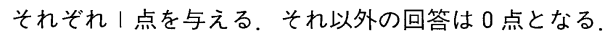

礎体力との関連性を調べる目的で調査を行った。

\section{対象と方法}

\section{1 対 象}

対象は, 茨城県那珂郡の養護老人ホーム入居者, お よび東京都多摩市の A 型軽費老人ホーム入居者, 計 110 名であった. 性別は男性 32 名, 女性 78 名で, 平均 年齢士標準偏差は, 男性 76.9 27.6 歳, 女性 $80.2 \pm 6.3$ 歳であった，対象の特性は表 2 に示したとおりであ る。また, 対象の入居している老人ホームの形態は異 なっていたが，身体的特性や活動性に大きな差はない ものと考えられた。その理由として，1）片麻痺など の重篤な運動機能障害がなかったこと， 2 ）食事, 排
泄，入浴といった身体的日常生活活動はすべて自立し ていたこと， 3 ）毎日の食事は給食を受けており，掃 除，洗濯，買い物といった手段的日常生活活動は本人 の能力により自由にこなしていること，4) 外出，外 泊，種々の社会活動は本人の意志にほほ任されている こと，などが挙げられた。また，抑うつ症状，痴呆症 状といった心理面, 知的機能面に問題があるとされた 者は対象から除外した。

\section{2 方 法}

測定項目は，高齢者用運動動機尺度（以後，動機尺 度と略す), および活動時歩数 (以後, 歩数と略す), 握力, 脚力, 肺活量であった.

動機尺度は，これまでわれわれが妥当性と信頼性を 検討してきたもので，4下位尺度，20 項目からなる質 
表 2 対象者特性

\begin{tabular}{|c|c|c|c|c|c|c|}
\hline & & & $\begin{array}{l}\text { 年 } \\
(\text { 歳) }\end{array}$ & ${ }^{\text {身 }}(\mathrm{cm})^{\text {長 }}$ & ${ }^{\text {体 }}{ }^{\text {kg })^{\text {重 }}}$ & $\begin{array}{c}\text { 居住期間 } \\
\text { (カ月） }\end{array}$ \\
\hline 男 & 性 & $n=32$ & $\begin{array}{l}76.9 \pm 7.6 \\
(62 \sim 89)\end{array}$ & $\begin{array}{l}156.6 \pm 7.5 \\
(|4| \sim 173)\end{array}$ & $\begin{array}{c}54.6 \pm 8.9 \\
(38 \sim 75)\end{array}$ & $\begin{array}{c}53.7 \pm 41.8 \\
(2 \sim 171)\end{array}$ \\
\hline 女 & 性 & $\mathrm{n}=78$ & $\begin{array}{l}80.2 \pm 6.3 \\
(64 \sim 92)\end{array}$ & $\begin{array}{l}143.0 \pm 6.1 \\
(133 \sim 163)\end{array}$ & $\begin{array}{c}45.1 \pm 8.0 \\
(29 \sim 61)\end{array}$ & $\begin{array}{c}62.3 \pm 81.3 \\
(3 \sim 262)\end{array}$ \\
\hline
\end{tabular}

問紙法尺度である。各下位尺度は，1）情動的要求： 運動の楽しさ，喜び，爽快さといった情動や，運動し たいという欲求そのものが運動動機につながるとする 因子, 2 ）健康生活：健康々のものや，健康的日常生 活を維持, 獲得したいという期待感が運動動機につな がるとする因子，3 ) 無能感と心身阻害：運動に対す る自信のなさや，運動が心身に弊害を及ぼすといった 意識が運動に対して回避動機となるとする因子，4) 社会生活：社会参加への希求, 人間関係の形成, 社会 生活を送るうえでの弊害を克服しようとする意欲が運 動動機につながるとする因子である，回答は，そう思 う，そう思わない，どちらでもない，から 1 つを選択 させ，運動に対して意欲的な回答のみに 1 点を与える 形式とした. したがって最大得点は 20 点, 最小得点は 0 点となる。本尺度は，個別面接法により聴取を行っ た。本動機尺度の内容を表 1 に示した。

身体活動性指標として歩数を用いた. 歩数の測定は, 1 週間の自己記録が必要であったため，はじめに全対 象者のなかから有志を募った。これら有志の内訳は, 男性 11 名, 女性 41 名であり，これらを歩数測定の対 象者とした，対象者には日中活動時, 歩数計を装着し, 装着した時刻，取り外した時刻，および歩数計に表れ た数値を 1 週間自己記録させた. 1 週間後, 途中棄権, 記入漏れのあった男性 2 名, 女性 3 名を除外し, 最終 的に 1 週間の自己記録が完了した男性 9 名, 女性 38 名 を分析対象とした。歩数計に表れる数值は, 個人の歩 容により若干の誤差を生じるため ${ }^{9,10)}$ ，あらかじめ 100 歩の歩行でどれだけの誤差を生じるか測定し補正係数 を求めた。これにより補正した歩数を装着時間数で除 し，日中 1 時間あたりに換算して值とした。歩数の測 定には電子万歩計（山佐時計計器社製，AS-200）を用 いた。

基礎体力の測定項目は握力, 脚力, 肺活量とした. 握力, 脚力は全身筋力の代表値と捉え, 肺活量は呼吸 予備能力の指標と捉えた。握力は，スメドレ一式握力
計にて左右 1 回ずつ測定し, 左右平均值を握力値とし た。脚力は椅子座位，膝関節 90 度屈曲位固定とし，等 尺性膝伸展力を測定した。左右 1 回ずつ測定し, 両者 の平均值を脚力值とした。測定には徒手筋力測定器 (OG 技研社製，Musculator GT-10）を用いた。肺活 量は，回転式肺活量計にて 2 回測定し，高い方の值を 採用した。

\section{3 統計解析}

動機尺度の信頼性の検討は Cronbach $\alpha$ によった. 相関関係の検定には Pearson の積率相関係数を用い た。また，運動動機と身体活動性，基礎体力の関係を 明確にするため, 歩数, 握力, 脚力, 肺活量をそれぞ れ従属変数, 性, 年歯, 身長, 体重, 動機尺度得点を 独立変数とした重回帰分析を行った．独立変数の選択 法は stepwise 法を用い, 独立変数の F 検定值が $5 \%$ 水 準に達しないものを除外した。性の変数に関しては, 男性 1 , 女性 2 のダミ一変数を用いた，統計学的有意 水準は危険率 $5 \%$ とした。解析には Statistical Analysis System（SAS インスティチュートジャパン社製） を用いた。

\section{結 果}

今回の調查における動機尺度の信頼性係数 （Cronbach $\alpha$ ) は, 情動的要求 0.71 , 健康生活 0.70 , 無能感 と心身阻害 0.74 , 社会生活 0.76 であった。

表 3 は動機尺度得点, 歩数, および各基礎体力項目 の測定結果を表している。動機尺度得点は, 男性が 13.5, 女性が 12.4 であった. 歩数は, 男性で 499.4 歩, 女性で 380.2 歩であった，各基礎体力項目は，握力が 男性 $30.3 \mathrm{kgw}$ ，女性 $20.1 \mathrm{kgw}$ ，脚力が男性 $28.3 \mathrm{kgw}$, 女性 $19.8 \mathrm{kgw}$, 肺活量が男性 $2,077.4 \mathrm{~m} l$, 女性 $1,479.4$ $\mathrm{m} l$ であった。 
表 3 運動動機尺度・身体活動および各基礎体力項目測定結果

\begin{tabular}{|c|c|c|c|c|c|c|}
\hline & & & 平均 & 標準偏差 & 最大值 & 最小值 \\
\hline \multirow[t]{2}{*}{ 動機尺度得点 } & 男性 & $\mathrm{n}=32$ & 13.5 & 4.0 & 20 & 2 \\
\hline & 女性 & $\mathrm{n}=78$ & 12.4 & 4.2 & 20 & 3 \\
\hline \multirow{2}{*}{$\begin{array}{l}\text { 活動時歩数 } \\
\text { (steps/hour) }\end{array}$} & 男性 & $\mathrm{n}=9$ & 499.4 & 375.1 & $1,138.0$ & 112.1 \\
\hline & 女性 & $\mathrm{n}=38$ & 380.2 & 234.4 & 945.7 & 64.4 \\
\hline \multirow{2}{*}{$\begin{array}{c}\text { 握 力 } \\
(\mathrm{kgw})\end{array}$} & 男性 & $n=32$ & 30.3 & 6.3 & 43.5 & 19.0 \\
\hline & 女性 & $\mathrm{n}=77$ & 20.1 & 3.9 & 28.3 & 10.5 \\
\hline \multirow{2}{*}{$\begin{array}{c}\text { 脚 } \\
(\mathrm{kgw})\end{array}$} & 男性 & $\mathrm{n}=32$ & 28.3 & 5.6 & 38.9 & 18.1 \\
\hline & 女性 & $\mathrm{n}=77$ & 19.8 & 5.5 & 31.3 & 6.7 \\
\hline \multirow{2}{*}{$\begin{array}{c}\text { 肺 活 量 } \\
(\mathrm{m} l)\end{array}$} & 男性 & $n=31$ & $2,077.4$ & 534.8 & $3,340.0$ & $1,080.0$ \\
\hline & 女性 & $n=63$ & $1,479.4$ & 370.8 & $2,920.0$ & 900.0 \\
\hline
\end{tabular}

表 4 各測定項目および年齢・身長・体重の相関行列

\begin{tabular}{|c|c|c|c|c|c|c|c|c|}
\hline & & 身長 & 体重 & 動機尺度 & 歩数 & 握力 & 脚力 & 肺活量 \\
\hline \multirow[t]{3}{*}{ 年 } & 齢 & -.33 & -.31 & -.06 & -.38 & -.42 & -.41 & -.35 \\
\hline & & $* * *$ & $* *$ & ns & $* *$ & $* * *$ & $* * *$ & $* * *$ \\
\hline & & 110 & 110 & 110 & 47 & 109 & 109 & 94 \\
\hline \multirow[t]{3}{*}{ 身 } & 長 & & .65 & 10 & 01 & .65 & .57 & .64 \\
\hline & & & $* * *$ & ns & ns & $* * *$ & $* * *$ & $* * *$ \\
\hline & & & 110 & 110 & 47 & 109 & 109 & 94 \\
\hline \multirow[t]{3}{*}{ 体 } & 重 & & & .15 & .09 & .58 & .60 & .56 \\
\hline & & & & ns & ns & $* * *$ & $* * *$ & $* * *$ \\
\hline & & & & 110 & 47 & 109 & 109 & 94 \\
\hline \multirow{3}{*}{\multicolumn{2}{|c|}{ 動機尺度 }} & & & & .35 & .26 & .30 & 28 \\
\hline & & & & & $*$ & $* *$ & $* *$ & $* *$ \\
\hline & & & & & 47 & 109 & 109 & 94 \\
\hline \multirow[t]{3}{*}{ 歩 } & 数 & & & & & .19 & .28 & 03 \\
\hline & & & & & & ns & ns & $\mathrm{ns}$ \\
\hline & & & & & & 47 & 47 & 43 \\
\hline \multirow[t]{3}{*}{ 握 } & 力 & & & & & & .76 & .70 \\
\hline & & & & & & & $* * *$ & $* * *$ \\
\hline & & & & & & & 109 & 93 \\
\hline \multirow[t]{3}{*}{ 脚 } & 力 & & & & & & & .66 \\
\hline & & & & & & & & $* * *$ \\
\hline & & & & & & & & 93 \\
\hline
\end{tabular}

マトリックス上段は相関係数, 中段は有意性検定結果 (ns : not significant, $*: p<.05, * *: p<.01, * * *: p<.001)$, 下段は人数を表す.

表 4 にこれら測定項目および年齢, 身長, 体重の単 相関係数を示した. 動機尺度得点を除く全ての項目は, 年齢と有意な相関を示した。握力，脚力，肺活量は， 身長，体重と有意な相関を示したが，動機尺度得点， 歩数は身長および体重とは有意な相関がみられなかっ た. 握力, 脚力, 肺活量はそれぞれ相互に有意な相関 関係を示した，動機尺度得点は，歩数とは危険率 $5 \%$, 脚力, 肺活量とは危険率 $1 \%$ で有意な相関を示した。

以上, 各体力指標は年齢や身長, 体重などの体格要
因から影響を受けることが明らかになったので，これ らの要因の影響を除いたうえで動機尺度得点と歩数お よび各基礎体力指標との関係を検討するため重回帰分 析を行った. 表 5 はその結果である. 動機尺度得点は, 歩数, 握力, 脚力, 肺活量のすべての従属変数におい て有意な変数として選択された。活動時歩数では, 最 も強い関連性を示したものは年齢で, 次に動機尺度得 点であった。このモデルにおける累積寄与率は $22.7 \%$ であった，握力に対し最も強い関連性を示したのは性 
表 5 重回帰分析結果

\begin{tabular}{|c|c|c|c|c|c|}
\hline 従属変数 & 独立変数 & 偏回帰係数 & 危険率 & 寄与率 & 累積寄与率 \\
\hline \multirow[t]{2}{*}{ 活動時歩数 } & 年 齢 & -15.72 & 0.0172 & 0.146 & \\
\hline & 動機尺度 & 20.55 & 0.0373 & 0.081 & 0.227 \\
\hline \multirow{4}{*}{ 握 力 } & 性 & -7.61 & 0.0001 & 0.496 & \\
\hline & 体 重 & 0.18 & 0.0004 & 0.083 & \\
\hline & 年＼cjkstart齢 & -0.22 & 0.0004 & 0.045 & \\
\hline & 動機尺度 & 0.28 & 0.0053 & 0.028 & 0.651 \\
\hline \multirow[t]{4}{*}{ 脚 力 } & 体 & 0.248 & 0.0001 & 0.356 & \\
\hline & 性 & -5.166 & 0.0001 & 0.113 & \\
\hline & 年＼cjkstart齢 & -0.216 & 0.0021 & 0.043 & \\
\hline & 動機尺度 & 0.340 & 0.0030 & 0.040 & 0.553 \\
\hline \multirow[t]{3}{*}{ 肺活量 } & 身 長 & 32.60 & 0.0001 & 0.406 & \\
\hline & 動機尺度 & 27.28 & 0.0065 & 0.047 & \\
\hline & “年＼cjkstart齢 & -13.66 & 0.0278 & 0.029 & 0.482 \\
\hline
\end{tabular}

であり，続いて体重，年齢，動機尺度の順であった． このモデルにおける 4 変数の累積寄与率は $65.1 \%$ で あった．脚力では，体重，性，年齢，動機尺度の順で 関連性が強かった。このモデルでの 4 変数の累積寄与

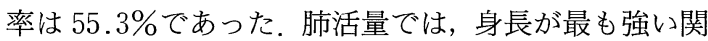
連性を示す独立変数であり, 続いて動機尺度得点, 年 齢の順であった. 3 変数の累積寄与率は $48.2 \%$ あっ た。各モデルにおける動機尺度得点の寄与率は $2.8 \%$ から $8.1 \%$ あったが，全てのモデルにおいて有意な 関連性が確認された。

\section{考 察}

動機は仮説構成概念であり，その測定は多くの問題 を含んでいるとされている しくは本動機尺度のような質問紙法がある。本調查に おける動機尺度の Cronbach $\alpha$ は, 情動的要求が 0.71 , 健康生活が 0.70 , 無能感と心身阻害が 0.74 , 社 会生活が 0.76 であった. Cronbach $\alpha$ に関しては有意 性の共通理解がなされているわけではないが，一般的 に，十分な信頼性を与えるのは 0.7 以上とされてい $ろ^{12)}$.この基準によれば, 本動機尺度は内部一貫性の観 点より，信頼性の確認がなされたことになる。また， 本動機尺度は, 高齢者からの聞き取り調査から項目を 抽出し，さらに因子分析といった数学的手続きを経て 項目を精選した。したがって，内容的妥当性および因 子的妥当性を満たしうるものと思われる．以上より本 動機尺度は，高齢者の運動動機を十分に測定しうる尺
度である。

本研究の目的は, 高齢者における運動動機, 運動意 欲といった心理的要因と身体活動性や基礎体力との関 係を客観的に検討することにあった。まず，動機尺度 得点と活動時歩数, 握力, 脚力, 肺活量との単相関係 数を見ると，それぞれの相関は弱いものであったが， 統計学的に有意であった. 歩数, 握力, 脚力, 肺活量 は，年齢と負の相関関係にあり，他の調查 ${ }^{13 \sim 17)}$ と同じ く, 60 歳以降でも緩やかに低下していくことが示され た，同様に，各基礎体力項目は身長，体重などの体格 要因との相関が高いことが明らかとなった，また，各 基礎体力には性差が認められた。したがって動機尺度 と歩数, 基礎体力項目の関係は，これらの要因を除外 したうえで検討する必要があるものと思われた。そこ で, 歩数, 握力, 脚力, 肺活量に影響を及ほす要因と して性, 年齢, 身長, 体重, 動機尺度を想定し, これ らを従属変数として重回帰分析を行った。 その結果, 動機尺度得点はこれら従属変数相互の影響を除外した 場合でも歩数, 握力, 脚力, 肺活量と統計学的に有意 であり，運動に対する動機と身体活動性や基礎体力と の間には関連性がないとはいえないことが示唆され た.

歩数による計測結果は, 対象者の歩行量すなわち日 常身体活動性を客観的に表す数值として捉えられてい る ${ }^{18,19)}$.また,これまで 1 日の歩行量は，1日のエネル ギー消費量や酸素摂取量と関連することが明らかにさ れておうう ${ }^{20 \sim 22)}$ ，高齢者でも体力や健康度の指標となり うるものと思われる. 歩数は年齢と動機尺度得点と関 連があり，この結果は年齢が若く，運動に対する動機 
が高い者ほど身体活動が活発であることを示唆してい る.動機は活動に対して時間的に先行する概念であり, 運動動機が高まれば，身体活動量が増加するという因 果関係を想定することができる。したがって，高齢者 の身体活動性を高めるためには運動に対する動機づけ が重要であると考えられる。しかし，歩数における動 機尺度の寄与率は, 他の基礎体力測定項目に比し低 かった. このことは, 高齢者の身体活動性には他の重 要な要因が関与していることを示唆している．高齢者 の身体活動性に影響を与える要因として, 就業の有無, 親戚や友人付き合いの程度といった社会的要因が強く 関与している可能性があり, 社会科学的見地からそれ らの関連性を検討していかなければならない. 今回測 定を行った基礎体力項目は，それぞれ握力および脚力 は全身筋力, 肺活量は呼吸予備能力の指標として捉え ることができ, 高齢者の健康的な生活にとって重要な 体力要素と考えられる. 握力に対する独立変数の関連 の強さは性, 体重, 年歯, 動機尺度得点の順であり, 脚力では体重, 性, 年齢, 動機尺度得点の順であった. 高齢者において, 筋力は筋量に左右されているとする 報告があるが23), 筋量は同時に性, 体重, 年齢の影響を 受けていると考えられる。 また，脚力については体重 の大きい者ほど脚力が強いことが示唆された. 脚力測 定に関しては, 徒手筋力測定器を用いた。この方法に よる筋力測定は験者間の再現性は高いとの報告がある が ${ }^{24)}$, 固定性に問題があり, 真の筋力は測定困難であろ うとの報告もある ${ }^{25)}$. 今回は同一験者による測定であ り, 徒手筋力検査法と比較して筋力の個人差を観測す る感度は高いものと思われた。これら握力, 脚力が動 機尺度得点と関連していたという結果は，性や年齢に よらず高い動機を有する者は高い身体活動性を有して いるため, 強い筋力を維持していたものと考えること ができる. 肺活量は運動能力に直接関与する呼吸系の 評価法であり，肺容積や呼吸筋機能に影響を受け，高 い肺活量を有することは, 高い運動能力を有するため の必要条件と考えられる。今回の測定では，肺活量は 身長との関連性が強かったが，同時に動機尺度得点や 年齢とも関連が示された。このことは, 肺活量に関し ても, 運動動機の高い者が比較的活発な身体活動を 行っているため, 身長や年齢によらず高い肺活量を維 持していたものと推察される.

以上，高齢者の運動動機と身体活動性，基礎体力の 関係について考察したが，これら身体活動性や基礎体
力は, 前述の社会的要因以外にも疾病, 障害の程度な どの要因に影響を受ける可能性がある，だが，高齢者 の疾病や障害は，すでに慢性化している場合が多く， 疾病の治癒や機能障害レベルの改善は困難であること が多いように見受けられる。したがって，高齢者の健 康づくりに必要な身体活動性を高めていくためには, 運動に対する動機づけは重要である．慢性的機能障害 を有する高齢者を対象とすることの多い地域リハビリ テーションにおける運動指導では, 楽しめる運動プロ グラムを考え, 進行に熟達し, 運動に内在する楽しさ や喜びを引き出す，運動と健康の関係をわかりやすく 教育し, informed consent を得るように努める。運動 プログラムは実施, 継続可能なものとし, 運動に対す る無能感を助長しないものとする．運動指導の場は社 会生活に通じる空口であるとの認識に立ち, 友達づく りの場の提供, 雲囲気づくりに留意するといったこと が運動動機を高める可能性があることが指摘できる.

\section{文 献}

1）日本体育協会：スポーツ選手の心理的適性に関する研 究. 第 3 報, 昭和 56 年度スポーツ科学班研究報告, 1981 .

2) 西田 保：体育における学習意欲の尺度構成と類型化 の検討. 総合保健体育科学 $10 ： 47-60,1987$.

3）猪俣公宏：運動意欲と運動嫌い. 体育科教育 $11: 21$ $-24,1989$.

4）西田 保, 猪俣公宏：スポーツにおける達成動機の因 子分析的研究. 体育学研究 $26: 101-110,1974$.

5) Butt DS : Short scales for the measurement of sports motivation. Int J Sports Psychol 10 : 203215, 1979.

6) Telama $R$, Silvennoinen $M$ : Structure and development of 11 to 19 years old motivation for physical activity. Scand J Sports Sci 1:23-31, 1979.

7）大友昭彦, 渡辺京子, 山田紀代美, 鈴木みずえ・他： 高齢者の運動動機構成因子の探索一高齢者用運動動機 尺度の開発に向けて一. 理学療法学 21:218-225, 1994.

8）大友昭彦, 渡辺京子, 山田紀代美, 鈴木みずえ・他： 高齢者用運動動機尺度の妥当性と信頼性の検討。理学 療法学 22:119-124, 1995.

9）大塚貴子：スポーツ医学からみた歩数計の使い方. 臨 床スポーツ医学 9:143-147, 1992.

10）岩月宏泰：万歩計による脳卒中片麻痺患者の歩行量測 定の有用性. 理学療法学 19:365-370, 1992.

11）浜 治世：講座 動機と情動の測定，動機と情動. 前 田嘉明(編) : 心理学 5 . 東京大学出版会, 東京, 1977 , pp. 83-108.

12) Carmines EG, Zeller RA : テストの信頼性と妥当性. 水野欽司 (訳) : 人間科学の統計学 7 . 朝倉書店, 東京, 
1983, pp. 34-60.

13）木村みさか，新井多聞，筒井康子，北村孝子・他：高 齢者を対象にした体力測定の試み 1.65 歳以上高齢者 の体力の現状. 日本公衛誌 $34: 33-40,1887$.

14）木村みさか, 平川和文，奥野 直，小田慶喜・他：体 力診断バッテリーテストからみた高齢者の体力測定值 の分布および年齢との関連. 体力科学 $38: 175-185$, 1989.

15）木村みさか，森本好子，寺田光世：都市在住高齢者の 運動習慣と体力診断バッテリーテストによる体力. 体 力科学 $40: 455-464,1991$.

16）大塚友吉，道免和久，里宇明元，園田 茂・他：高齢 者の握力一測定法と正常值の検討一. リ八医学 31 ： 731-735, 1994 .

17）平野裕一, 野口秋実, 宮下充正：加齢にともなう膝伸 展パワー值の変化とその評価. 体力科学 $43: 113-$ 120, 1994.

18）星川 保, 松井秀治, 出原鎌雄, 佐野 智：ペドメー 夕歩数からみた小学校 5,6 年生の日常生活における 身体活動量. 体育科学 $15 ： 56-66,1987$.

19）星川 保, 森 悟, 松井秀治：中学生の日常身体活動 量一カロリーカウンターとペドメータによるー。体育
科学 19:7-19, 1991.

20）星川 保：ペドメータに基づいた運動の消費カロリー の算出法とその問題点. 体育の科学 $\mathbf{3 6}: 864-869$, 1986.

21）戎 利光, 斉藤由美, 島田 茂, 加藤孝之：1日当り のエネルギー消費量とペドメータ歩数との相互関係. デサントスポーツ科学 11：115-123，1990.

22）星川 保, 豊島進太郎, 近藤 鈔, 出原鎌雄・他：ぺ ドメータ歩数と酸素摂取量との関係一中学校体育のバ レーボール, サッカー, バスケットボール教材につい て一。体育科学 14:7-14, 1986.

23) Reed LR, Pearlmutter L, Yochum K, Meredith KE, et al: The relationship between muscle mass and muscle strength in the elderly. J Am Geriatr Soc 39 : 555-561, 1991.

24) Bohannon RW, Andrew AW : Interrater reliability of hand-held dynamometry. Phys Ther 67:931933, 1987.

25）奈良 勲, 州崎俊男, 浅井 仁, 山崎俊明：ダイナモ メーターの信頼性一Musculater GT10 の使用経験に よる一. 理学療法学 17：247-250, 1990.

$*$

\title{
Relationship between Motive for Exercise, Physical Activity, and Basic Physical Fitness in the Elderly
}

by

\author{
Akihiko Oтомо*1, Kyouko $\mathrm{W}_{\text {ATANABE }}{ }^{* 2}$, Shigeru TsuchiYA ${ }^{* 3}$, Masatoshi TANAKA ${ }^{* 1}$ \\ from \\ ${ }^{* 1}$ Department of Hygiene and Preventive Medicine, Fukushima Medical College \\ ${ }^{* 2}$ Department of Rehabilitation Center, Kameda General Hospital \\ ${ }^{*}$ Institute of Community Medicine, Tsukuba University
}

\section{(Jpn J Rehabil Med $33:$ 400-406, 1996)}

This study was conducted to clarify the relationship between the motive for exercise and physical activity, and the relationship between the motive and basic physical fitness in the elderly. The subjects were 110 residents in two types of nursing home. They measured the newly developed exercise motive scale for the elderly, daytime step rate, grip strength, leg strength, and vital capacity. Scores of the exercise motive scale for the elderly significantly related to daytime step rate, grip strength, leg strength, and vital capacity, respectively, excluding the effects of age, gender, height, and weight by the multiple regression analysis. It was suggested that the exercise motive contributed to the level of physical exercise in the elderly people. The stimulation of motive for exercise is encouraged in the elderly people for their health promotion. 